\title{
Availability of fertiliser sulphate and elemental sulphur to canola in two consecutive crops
}

\author{
Fien Degryse • Babasola Ajiboye • Roslyn Baird • \\ Rodrigo C. da Silva $\cdot$ Mike J. McLaughlin
}

Received: 5 July 2015 / Accepted: 8 September 2015 /Published online: 15 September 2015

(C) The Author(s) 2015. This article is an open access publication, corrected publication August/2017

\begin{abstract}
Aims We compared elemental sulphur (ES) and sulphate fertilisers in terms of yield and S uptake.

Methods Two consecutive canola crops were grown on

${ }^{35}$ S-labelled soil amended with ammonium sulphate, ES-bentonite pastilles (90 \% ES), or S-fortified ammonium phosphate (NP) fertilisers containing both sulphate-S and ES (5-8 \% ES). The shoot yield, S concentration and specific activity of $\mathrm{S}$ in the shoot were determined.

Results In the first crop, the yield was significantly lower in the control (without added ES) and ES pastille treatments than in the other treatments. Sulphur uptake was highly correlated with the added sulphate rate. In the second crop, the yield and S uptake was highest for
\end{abstract}

The original version of this article was revised due to a retrospective Open Access order.

Responsible Editor: Philip John White

Electronic supplementary material The online version of this article (doi:10.1007/s11104-015-2667-2) contains supplementary material, which is available to authorized users.

F. Degryse $(\bowtie) \cdot$ B. Ajiboye $\cdot$ R. Baird $\cdot$ R. C. da Silva M. J. McLaughlin

Adelaide University Fertiliser Technology Research Centre, Soil Science Group, School of Agriculture, Food and Wine, The

University of Adelaide, PMB 1 Waite Campus, Glen Osmond, SA

5064, Australia

e-mail: fien.degryse@adelaide.edu.au

B. Ajiboye

e-mail: babasola.ajiboye@yahoo.com

R. Baird

e-mail: roslyn.baird@adelaide.edu.au the S-fortified NP fertilizers. The contribution of ES to the S uptake was circa $20 \%$ in the first crop and $43 \%$ in the second crop for the S-fortified NP fertilisers, but was negligible for the ES pastilles. Modelling indicated an oxidation rate of $0.6-0.7 \%$ per day for the S-fortified NP fertilisers and $0.03 \%$ per day for the ES pastilles. Conclusions The contribution of ES pastilles to $\mathrm{S}$ uptake was negligible in both crops. In contrast, Sfortified NP fertilisers showed a significant contribution of ES and higher $S$ availability than sulphate-only fertiliser in the second crop.

Keywords Elemental sulphur Fertiliser - Oxidation rate $\cdot$ Canola

\footnotetext{
R. C. da Silva

e-mail: rodrigo.coquidasilva@adelaide.edu.au

M. J. McLaughlin

e-mail: michael.mclaughlin@adelaide.edu.au

B. Ajiboye

Sulvaris Inc., 6443 2nd St SE, Calgary, AB T2H 1J5, Canada

M. J. McLaughlin

CSIRO Agriculture Flagship, PMB 2, Glen Osmond, SA 5064, Australia
} 


\section{Introduction}

Sulfur (S) is an essential element for plant growth. The yearly export of $\mathrm{S}$ in harvested products ranges from 4 to $30 \mathrm{~kg} \mathrm{ha}^{-1}$ (Zhao et al. 2002), and is of same order of magnitude as that of $\mathrm{P}$. Nevertheless, $\mathrm{S}$ has received relatively little attention as a plant nutrient, because inputs through atmospheric deposition and application of S-containing macronutrient fertilisers (e.g. single super phosphate) were usually sufficient to fulfil the crop demand. However, S inputs have decreased in many regions over the last decades because of a decrease in atmospheric S deposition due to stricter pollution control and because of a shift towards high-analysis S-free fertilizers. On the other hand, crop removal of S in new high-yielding varieties has increased (Bender et al. 2013). As a result, $S$ deficiency has become more frequent in many agricultural areas (Scherer 2001; Haneklaus et al. 2008), resulting in an increased need for S fertilization (Ceccotti 1996).

Sulphur in inorganic fertilisers is usually present as sulphate (e.g. in ammonium sulphate or gypsum) or as elemental sulphur (ES). Sulphate is immediately available to plants but is susceptible to leaching. Elemental S does not leach and has the benefit of a low transport cost (as it is $100 \% \mathrm{~S}$ ), but only becomes available to plants after oxidation (Boswell and Friesen 1993). It is therefore important to know the oxidation rate of ES in the fertiliser in order to assess if the $\mathrm{S}$ supply meets the plant demand and to develop or adjust fertiliser strategies accordingly.

Most studies on oxidation and plant availability of ES have been carried out with ES particles mixed through soil. Oxidation of ES is a microbial process and has been shown to strongly depend on temperature (Janzen and Bettany 1987). The rate of oxidation decreases with increasing ES particle size, as ES oxidation is a surficial process (Germida and Janzen 1993). Also soil properties play a role, likely due to the effect of soil physicochemical properties on microbial population, aeration and substrate availability (Germida and Janzen 1993). As the oxidation of ES is highly dependent on particle size, in principle, ES particles of a given size can be selected to supply sulphate over a given period for a particular region (Boswell and Friesen 1993).

While finely divided ES powder has been shown to supply sulphate in the short term, powdered ES is not a practical commercial fertiliser, due to the difficulties in handling powders and the explosion hazard of finely divided ES (Chien et al. 2011). Commercial ES fertilisers often consist of prills or pastilles with high ES content (usually $>80 \%$ ES) and a small amount of binder (often bentonite). Some studies have found that easily dispersible ES prills can quickly disintegrate into fine particles when surface-applied and show considerable oxidation in the short term (Boswell et al. 1988b), but most studies have found little effect of pastilles or prills in the first year of application (e.g. Karamanos and Janzen 1991; Malhi et al. 2008; Riley et al. 2000), likely due to lack of dispersion. If and how quickly the pastilles or prills disperse depends on several factors, such as the method of application, the amount and type of binder and the climatic conditions (Boswell et al. 1988a; Solberg et al. 2003).

Elemental S-fortified macronutrient formulations are another type of commercial ES-containing fertiliser. In these ES-fortified (also termed sulphur enhanced) products, ES is either dispersed throughout the fertiliser granule or coated onto the granule. There are several commercial products available, with for instance urea, triple super phosphate (TSP), monoammonium phosphate (MAP) or diammonium phosphate (DAP) as the macronutrient carrier. However, there is little information on the oxidation rate of ES in these products and the $\mathrm{S}$ availability to plants. It is known that co-granulation of ES particles with macronutrient fertiliser generally reduces the rate of oxidation compared to when ES particles of the same size are mixed through soil (Friesen 1996). In a recent study, we evaluated the oxidation rate of ES in commercial fertilisers in three soils at $25{ }^{\circ} \mathrm{C}$, and found that the (first-order) oxidation rate of ES in ES-fortified MAP fertiliser with 5-7.5\% ES was around $0.5 \%$ per day (i.e. half-life of oxidation $\sim 140 \mathrm{~d}$ ), compared to around $2 \%$ per day (half-life of $35 \mathrm{~d}$ ) for ES particles of similar size (diameter $<100 \mu \mathrm{m}$ ) and around $0.06 \%$ per day (half-life $\sim 1200 \mathrm{~d}$ ) for ES pastilles (Degryse et al. 2015). However, further evaluation of these products in pot trial and field trials is still needed to assess their agronomic effectiveness.

The aims of this study were to assess the contribution made by ES in commercial fertilisers to the uptake of $\mathrm{S}$ by plants and to estimate the oxidation rate of ES under plant growth conditions. The products we tested included ES pastilles and ES-fortified ammonium phosphate fertilisers. Canola was used as the test plant because of its high $\mathrm{S}$ requirement (Grant et al. 2012). We used an indirect labelling technique with ${ }^{35} \mathrm{SO}_{4}$-labelled soil in order to 
estimate the contribution of ES to the S uptake by plants.

\section{Materials and methods}

Soil pre-incubation

Soil was collected from Monarto (South Australia) to $10 \mathrm{~cm}$ depth, air-dried and sieved to less than $2 \mathrm{~mm}$ prior to characterization (Table 1). The soil was brought to field capacity ( $13 \mathrm{ml}$ per $100 \mathrm{~g}$ ) and spiked with radioactive ${ }^{35} \mathrm{SO}_{4}(\beta$-emitter, half-life $87.5 \mathrm{~d})$ at an activity of $2.4 \mathrm{MBq} \mathrm{kg}^{-1}$ soil. Basal fertilisation was added to the soil as urea, $\mathrm{KCl}$ and $\mathrm{ZnCl}_{2}$, taking into account the nutrients added with the MAP and $\mathrm{S}$ fertiliser (see below) so that the added nutrient rates were $47 \mathrm{mg} \mathrm{N} \mathrm{kg}^{-1}, 20 \mathrm{mg} \mathrm{K} \mathrm{kg}{ }^{-1}$ and $2.4 \mathrm{mg} \mathrm{Zn} \mathrm{kg}^{-1}$ in all treatments. The soil was incubated in bags at $20^{\circ} \mathrm{C}$. Sulphate extraction (see below) was carried out weekly for each bag, starting at 14 days after spiking, until 7 weeks after spiking.

Fertiliser treatments and plant growth

At 50 days after spiking the ${ }^{35} \mathrm{SO}_{4}$, the soils were potted (1 kg per pot) in closed pots (no drainage allowed), and the fertiliser treatments (Table 2) were applied. The $\mathrm{S}$ fertilisers used were ammonium sulphate (AS, $24 \% \mathrm{~S}$ ),

Table 1 Selected soil characteristics

\begin{tabular}{ll}
\hline Location & Monarto (SA) \\
\hline Soil order & Alfisol \\
$\left.\mathrm{pH}^{(\mathrm{CaCl}}\right)^{\mathrm{a}}$ & 7.0 \\
$\mathrm{OC}^{\mathrm{b}}(\%)$ & 1.0 \\
$\mathrm{CEC}^{\mathrm{c}}\left(\mathrm{cmol}_{\mathrm{c}} / \mathrm{kg}\right)$ & 8.2 \\
$\mathrm{Clay}^{\mathrm{d}}(\%)$ & 8.3 \\
$\mathrm{Silt}^{\mathrm{d}}(\%)$ & 7.1 \\
$\mathrm{Sand}^{\mathrm{d}}(\%)$ & 81 \\
${\text { Total S }\left(\mathrm{mg} \mathrm{kg}^{-1}\right)}_{\mathrm{SO}_{4}-\mathrm{S}\left(\mathrm{mg} \mathrm{kg}^{-1}\right)}$ & 149 \\
\hline
\end{tabular}

${ }^{\mathrm{a}} \mathrm{pH}$ determined in $0.01 \mathrm{M} \mathrm{CaCl}_{2}\left(\mathrm{~L}: \mathrm{S} 5 \mathrm{~L} \mathrm{~kg}^{-1}\right)$

${ }^{\mathrm{b}}$ Organic carbon determined by dry combustion (Matejovic 1997)

${ }^{\mathrm{c}}$ Cation exchange capacity measured with $1 \mathrm{M}$ ammonium acetate at pH 7.0 (Rayment and Higginson 1992)

${ }^{\mathrm{d}}$ Particle size analysis with the pipette method (McKenzie et al. 2002)
Tiger90 ${ }^{\circledR}$ (Tiger-Sul), Granulock $\mathrm{S}^{\circledR}$ (Incitec Pivot) and MicroEssentials SZ ${ }^{\circledR}$ (MESZ, The Mosaic Company). Tiger90 consists of split-pea shaped ES:bentonite pastilles (SB) with $90 \%$ ES and $10 \%$ bentonite. Granulock S $(16 \% \mathrm{~N}, 16.7 \% \mathrm{P}, 12 \% \mathrm{~S})$ and MESZ $(12 \% \mathrm{~N}$, $17.6 \% \mathrm{P}, 10 \% \mathrm{~S}, 1 \% \mathrm{Zn})$ are granular ES-fortified ammonium phosphate (SfNP) fertilisers. Granulock $\mathrm{S}$ (SfNP1) contains $4 \% \mathrm{SO}_{4}$-S and $8 \%$ ES and MESZ (SfNP2) contains $5 \% \mathrm{SO}_{4}$-S and $5 \%$ ES. A control treatment without $\mathrm{S}$ fertiliser was also included. To have a similar $\mathrm{P}$ rate for all treatments, monoammonium phosphate (MAP; $12 \% \mathrm{~N}, 22.7 \% \mathrm{P}, 1.6 \% \mathrm{~S}$ ) was added to the control, AS and ES pastille treatments at $200 \mathrm{mg} \mathrm{kg}^{-1}$ which also added $3.2 \mathrm{mg} \mathrm{SO}_{4}-\mathrm{S} \mathrm{kg}^{-1}$. The ES-containing fertilisers were added to have a total added $\mathrm{S}$ rate of $20 \mathrm{mg} \mathrm{kg}^{-1}$. The AS fertiliser was added at the same $\mathrm{SO}_{4}-\mathrm{S}$ rate as for the SfNP1 $\left(6.7 \mathrm{mg} \mathrm{SO}_{4^{-}}\right.$ $\left.\mathrm{S} \mathrm{kg}^{-1}\right)$ or SfNP2 (10 $\left.\mathrm{mg} \mathrm{SO}_{4}-\mathrm{S} \mathrm{kg}^{-1}\right)$ treatments, or at the same total $\mathrm{S}$ rate as for the ES-containing fertilisers (20 mg S kg-1). All treatments were replicated four times. The pots were arranged randomly and rerandomised daily when watering.

Six seeds of canola (Brassica napus) were placed in the soil in a circle $1 \mathrm{~cm}$ below the soil surface. The fertiliser granules were placed in the soil, $2 \mathrm{~cm}$ below the soil surface, equally spaced in a circle at a distance of $2.5 \mathrm{~cm}$ from the seeds. Plants were thinned to four, 1 week after sowing. Soils were top-dressed with urea $\left(47 \mathrm{mg} \mathrm{N} \mathrm{kg}^{-1}\right)$ at 3 weeks after sowing. The pots were watered to field capacity on a daily basis and plants were harvested after 6 weeks.

After the first crop, the soil was removed from each pot, well mixed and sulphate was extracted from a 4-g sub-sample, after which the soils was placed back in the pot and left open to the atmosphere. At 38 days after the harvest of the first crop, the soil was rewetted to field capacity and a second canola crop was planted (six seeds, thinned to four after 1 week). Soils were topdressed with urea $\left(47 \mathrm{mg} \mathrm{N} \mathrm{kg}^{-1}\right)$ at 1, 3 and 5 weeks after sowing. More $\mathrm{N}$ was added to the second crop to compensate for depletion of available $\mathrm{N}$ in soil in the first crop. The plants were harvested after 6 weeks of growth. The soils were again mixed and $\mathrm{SO}_{4}-\mathrm{S}$ extraction was carried out on a sub-sample.

Soil and plant analysis

Dry matter yield of the harvested shoots was determined after oven-drying at $60{ }^{\circ} \mathrm{C}$ to constant weight. The dried 
Table 2 Rates of sulphate $\mathrm{S}\left(\mathrm{SO}_{4}-\mathrm{S}\right)$, elemental S (ES) or total S added in the different fertiliser treatments (MAP: monoammonium phosphate; AS: ammonium sulphate; SB: sulphur-bentonite pastilles; SfNP: ES-fortified ammonium phosphate fertilisers). The values in brackets following the treatment name indicate the added $\mathrm{SO}_{4}-\mathrm{S}$ and $\mathrm{ES}$ rate (in $\mathrm{mg} \mathrm{kg}^{-1}$ )

\begin{tabular}{|c|c|c|c|c|}
\hline \multirow[b]{2}{*}{ Treatment $\left(\mathrm{SO}_{4}-\mathrm{S} / \mathrm{ES}\right)$} & \multicolumn{2}{|c|}{$\mathrm{SO}_{4}-\mathrm{S}\left(\mathrm{mg} \mathrm{kg}^{-1}\right)$} & \multirow[t]{2}{*}{$\mathrm{ES}\left(\mathrm{mg} \mathrm{kg}^{-1}\right)$} & \multirow[t]{2}{*}{ Total S (mg kg $\left.{ }^{-1}\right)$} \\
\hline & MAP & $\mathrm{S}$ fertiliser & & \\
\hline \multicolumn{5}{|l|}{$\mathrm{SO}_{4}-\mathrm{S}$ only treatments } \\
\hline MAP (3.2) & 3.2 & na & 0 & 3.2 \\
\hline AS (6.7) & 3.2 & 3.5 & 0 & 6.7 \\
\hline AS (10) & 3.2 & 6.8 & 0 & 10 \\
\hline AS (20) & 3.2 & 16.8 & 0 & 20 \\
\hline \multicolumn{5}{|l|}{ ES treatments } \\
\hline $\mathrm{SB}(3.2 / 16.8)^{\mathrm{a}}$ & 3.2 & 0 & 16.8 & 20 \\
\hline $\operatorname{SfNP} 1(6.7 / 13.3)^{\mathrm{b}}$ & 0 & 6.7 & 13.3 & 20 \\
\hline SfNP2 $(10 / 10)^{c}$ & 0 & 10 & 10.0 & 20 \\
\hline
\end{tabular}

na not applicable

${ }^{\text {a }}$ Sulphur-bentonite pastilles, containing $90 \%$ ES (Tiger90)

${ }^{\mathrm{b}} \mathrm{S}$-fortified ammonium phosphate fertiliser with $4 \% \mathrm{SO}_{4}-\mathrm{S}$ and $8 \% \mathrm{ES}$ (Granulock S)

${ }^{\mathrm{c}} \mathrm{S}$-fortified ammonium phosphate fertiliser with $5 \% \mathrm{SO}_{4}$-S and $5 \% \mathrm{ES}$ (MicroEssentials SZ)

shoot samples were digested in hot concentrated nitric acid. Sulphate extraction on the soil samples was carried out with $0.01 \mathrm{M} \mathrm{Ca}\left(\mathrm{H}_{2} \mathrm{PO}_{4}\right)_{2}$ at liquid:solid ratio of $5 \mathrm{~L} \mathrm{~kg}^{-1}$ (Barrow 1967). The suspensions were shaken on an end-over-end shaker for $1 \mathrm{~h}$ and filtered over $0.45 \mu \mathrm{m}$. The digests and extracts were analysed by ICP-OES (inductively-coupled plasma optical emission spectroscopy; Perkin Elmer Optima 7000DV) for total S and by liquid scintillation counting (Tri-Carb 3110 TR; Perkin Elmer) for radioactive ${ }^{35} \mathrm{~S}$. All ${ }^{35} \mathrm{~S}$ activities were decay-corrected to the same date and specific activities (SA; ratio of ${ }^{35} \mathrm{~S}$ to stable $\mathrm{S}$ ) in the soil extracts and in the plant digests were calculated. Since the $0.01 \mathrm{M} \mathrm{Ca}\left(\mathrm{H}_{2} \mathrm{PO}_{4}\right)_{2}$ extracts mainly sulphate, the $\mathrm{Ca}\left(\mathrm{H}_{2} \mathrm{PO}_{4}\right)_{2}$ - extractable concentrations were considered a measure of sulphate (Barrow 1967). However, it should be noted that ICP-OES measures total $\mathrm{S}$ in solution, not just $\mathrm{SO}_{4}-\mathrm{S}$, so some organic $\mathrm{S}$ may also have been included (Zhao and McGrath 1994).

The percentage of plant S derived from ES (\%SdfES) was estimated by comparing the SA of plants grown on the ES-fertiliser treatments to those in the $\mathrm{SO}_{4}-\mathrm{S}$ only treatment with same added $\mathrm{SO}_{4}-\mathrm{S}$ rate:

$\%$ SdfES $=100 \cdot\left(1-\frac{\mathrm{SA}_{\text {plant }}}{\mathrm{SA}_{\text {plant,ref }}}\right)$ where $\mathrm{SA}_{\text {plant }}$ is the specific activity of shoot $\mathrm{S}$ for the ES-fertiliser treatment and $\mathrm{SA}_{\text {plant,ref }}$ for the reference treatment with same $\mathrm{SO}_{4}$-S addition rate (i.e., MAP for $\mathrm{SB}, \mathrm{AS}(6.7)$ for SfNP1, and $\mathrm{AS}(10)$ for SfNP2; cf. Table 2).

Statistical analysis

Statistical significance of the differences was determined by one-way ANOVA, using Duncan's multiple range test for post hoc comparison (SPSS, Release 19).

\section{Modelling}

In order to estimate the oxidation rate of ES in the fertilisers, we developed a simple model describing the $\mathrm{S}$ fluxes in the system. The uptake rate of sulphate was assumed to be proportional to the sulphate concentration in the soil:

$F_{\text {upt }}=\alpha\left[\mathrm{SO}_{4}\right]$

with $F_{\text {upt }}$ the uptake rate expressed per plant dry weight (DW) $\left(\mathrm{mg} \mathrm{S}(\mathrm{g} \mathrm{DW})^{-1} \mathrm{~d}^{-1}\right)$, $\left[\mathrm{SO}_{4}\right]$ the sulphate concentration in soil (mg S $\left.(\mathrm{kg} \mathrm{soil})^{-1}\right)$ and $\alpha$ the uptake coefficient $\left(\mathrm{kg}(\mathrm{g} \mathrm{DW})^{-1} \mathrm{~d}^{-1}\right)$. Active uptake of solutes is commonly described with Michaelis-Menten kinetics 
(Barber 1995), which can be simplified to a linear relationship between uptake flux and concentration in the surrounding medium at concentrations below the halfsaturation constant $\left(\mathrm{K}_{\mathrm{m}}\right)$. Our results indicated that uptake did not approach saturation (see below), justifying the use of a linear relationship.

The change in $\mathrm{SO}_{4}-\mathrm{S}$ concentration was calculated from the uptake rate (consumption of $\mathrm{SO}_{4}-\mathrm{S}$ ) and the $\mathrm{ES}$ oxidation rate (production of $\mathrm{SO}_{4}-\mathrm{S}$ ) for treatments with ES-containing fertiliser:

$\frac{d\left[\mathrm{SO}_{4}\right]}{d t}=-F_{\text {upt }} \cdot \frac{W_{\text {plant }}}{W_{\text {soil }}}+F_{\text {oxid }}$

where $W_{\text {plant }}$ and $W_{\text {soil }}$ are the weight of the plant ( $\mathrm{g}$ DW) and of the soil $(\mathrm{kg})$ and $F_{\text {oxid }}$ the ES oxidation rate (mg (kg soil) $\left.{ }^{-1} \mathrm{~d}^{-1}\right)$. Furthermore, it was assumed that $3.4 \mathrm{mg} \mathrm{SO}{ }_{4}-\mathrm{S} / \mathrm{kg}$ was added to the sulphate pool between the first and second crop due to mineralization of organic $\mathrm{S}$, for reasons discussed in the Results section.

The oxidation rate was assumed to follow first-order kinetics $\left(F_{\text {oxid }}=k_{\text {oxid }} \cdot \mathrm{ES}\right)$ :

$\mathrm{ES}_{t}=\mathrm{ES}_{\text {ini }} \cdot \exp \left(-k_{\text {oxid }} \cdot t\right)$

with $\mathrm{ES}_{t}$ and $\mathrm{ES}_{\text {ini }}$ the $\mathrm{ES}$ concentration $\left(\mathrm{mg} \mathrm{kg}^{-1}\right)$ at time $t$ (in days) and at the start of the experiment, respectively, and $k_{\text {oxid }}$ the relative oxidation rate constant $\left(\mathrm{d}^{-1}\right)$. Theoretically, oxidation of spherical ES particles does not follow an exponential relationship, but a cubic equation which takes into account the decrease in particle size as oxidation progresses (Watkinson 1989). However, the exponential approximation only starts to deviate considerably from the theoretical curve in the last stages of the oxidation $(<25 \% \mathrm{ES}$ left) and was selected for its ease of implementation and interpretation. Moreover, in practice, the ES used does not consist of single-sized spherical particles and we found in previous experiments that the exponential equation gives a better description of the oxidation than a cubic equation (unpublished results).

The plant growth was described with exponential growth kinetics:

$\frac{d W_{\text {plant }}}{d t}=\mu \cdot W_{\text {plant }}$

where $\mu$ is the relative growth rate $\left(\mathrm{d}^{-1}\right)$. To take into account nutrient limitation in the S-deficient treatments, the growth rate was modified depending on the internal $\mathrm{S}$ concentration as follows:

$\mu=\mu_{\max }$ if $\left[\mathrm{S}_{\text {plant }}\right]>\left[\mathrm{S}_{\text {plant }}\right]_{\text {crit }}$

$\mu=\frac{F_{\text {upt }}}{\left[\mathrm{S}_{\text {plant }}\right]_{\text {crit }}}$ if $\left[\mathrm{S}_{\text {plant }}\right]=\left[\mathrm{S}_{\text {plant }}\right]_{\text {crit }}$

where $\left[\mathrm{S}_{\text {plant }}\right]$ is the $\mathrm{S}$ concentration in the plant shoot $\left(\mathrm{mg} \mathrm{S}\left(\mathrm{g} \mathrm{DW}^{-1}\right)\right),\left[\mathrm{S}_{\text {plant }}\right]_{\text {crit }}$ the critical concentration below which the growth rate is reduced and $\mu_{\max }$ is the growth rate when $\mathrm{S}$ is not limiting. Thus, at low ( $\mathrm{S}$ deficient) supply, the growth rate is proportional to the uptake rate and the shoot $\mathrm{S}$ concentration equals the critical concentration. Similar concepts of nutrient limitation have been used to describe trace metal limitation to phytoplankton growth (Morel et al. 1991).

The change in plant $\mathrm{S}$ was calculated as:

$\frac{d \mathrm{~S}_{\text {plant }}}{d t}=F_{\text {upt }} \cdot W_{\text {plant }}$

with $\mathrm{S}_{\text {plant }}$ the amount of $\mathrm{S}$ taken up by the plant (mg S).

The change in ${ }^{35} \mathrm{SO}_{4}$ activity in the soil was calculated from the sulphate uptake and the specific activity of sulphate in soil:

$\frac{d\left[{ }^{35} \mathrm{SO}_{4}\right]}{d t}=-F_{\text {upt }} \cdot \frac{W_{\text {plant }}}{W_{\text {soil }}} \cdot \mathrm{SA}_{\mathrm{SO}_{4}}$

with $\left[{ }^{35} \mathrm{SO}_{4}\right]$ the activity of ${ }^{35} \mathrm{SO}_{4}\left(\mathrm{~Bq}(\mathrm{~kg} \text { soil })^{-1}\right)$ and $\mathrm{SA}_{\mathrm{SO} 4}$ the specific activity of soil sulphate $\left(\mathrm{Bq} \mathrm{mg}^{-1}\right)$, i.e. the ratio of $\left[{ }^{35} \mathrm{SO}_{4}\right]$ and $\left[\mathrm{SO}_{4}\right]$. The change in ${ }^{35} \mathrm{~S}$ activity in the plant was calculated as:

$\frac{d^{35} \mathrm{~S}_{\text {plant }}}{d t}=F_{\text {upt }} \cdot W_{\text {plant }} \cdot \mathrm{SA}_{\mathrm{SO}_{4}}$

with ${ }^{35} \mathrm{~S}_{\text {plant }}$ the ${ }^{35} \mathrm{~S}$ activity in the plant (Bq). The specific activity in the plant $\left(\mathrm{SA}_{\text {plant }}\right)$ was calculated as the ratio between ${ }^{35} \mathrm{~S}$ activity and total $\mathrm{S}$ in plant.

Equations (2)-(9) were numerically solved in Excel, using initial conditions as specified in the Results section and a time step of 0.5 day. An example of these numerical calculations is provided as a Supplementary File. 


\section{Results}

Yield and S uptake

In the first crop, the yield in the control (MAP only) and SB (pastilles) treatments was significantly lower than for the treatments with AS and the S-fortified NP fertilisers (Table 3). In the second crop, the yield was also the lowest for the control and SB treatments and highest for the treatments with S-fortified NP fertilisers. In contrast with the first crop, the yield was also reduced and not significantly different from the control treatment for the AS treatments at the lower rates (same sulphate addition as with the S-fortified NP fertilisers). There was no yield reduction for the AS treatment at the highest rate compared to the S-fortified NP fertilizers, but the plants displayed $\mathrm{S}$ deficiency symptoms (pale green younger leaves).

The $\mathrm{S}$ concentrations in the shoot confirmed that the observed reduction in plant growth was related to $\mathrm{S}$ deficiency. The $\mathrm{S}$ concentrations in the shoot were generally around $1 \mathrm{~g} \mathrm{~kg}^{-1}$ for the treatments with the lower yields and $>1.1 \mathrm{~g} \mathrm{~kg}^{-1}$ for treatments with no yield reduction (Table 3, Fig. 1). This relationship between dry matter yield and $\mathrm{S}$ concentration in whole shoot agrees well with results observed by Pinkerton (1998) for rapeseed at 51 days after sowing. The relationship

Table 3 The shoot dry matter yield (DMY), S concentration in the shoot $\left(\mathrm{S}_{\text {shoot }}\right)$, S uptake, and specific activity of shoot $\mathrm{S}\left(\mathrm{SA}_{\text {plant }}\right)$ in the first and second canola crop. The values in brackets following the treatment name indicate the added $\mathrm{SO}_{4}$-S and ES rate between relative yield (RY) and plant tissue concentration was well described by following equation (Fig. 1):

$\mathrm{RY}=1-\exp \left[-3.15\left(\left[\mathrm{~S}_{\text {plant }}\right]-0.57\right)\right]$

This equation predicts a critical plant concentration corresponding to $80 \%$ of the maximum yield of $1.09 \mathrm{~g} \mathrm{~kg}^{-1}$.

In the first crop, the $\mathrm{S}$ uptake increased with increasing $\mathrm{SO}_{4}$-S rate (Fig. 2). There was no significant difference in S uptake between the control and SB treatment. However, S uptake was significantly higher for the treatments with S-fortified NP fertilisers than for the corresponding AS treatments (i.e. the treatments with same $\mathrm{SO}_{4}-\mathrm{S}$ addition rate), indicating that there was some contribution of ES in these fertilisers to the uptake of $\mathrm{S}$ by plants. In the second crop, there was no clear relationship between the added sulphate rate and $\mathrm{S}$ uptake, with $\mathrm{S}$ uptake for the treatments with $\mathrm{S}-$ fortified NP fertilisers about 2-fold higher than for the corresponding AS treatments.

\section{Contribution of ES to S uptake}

The SA in the shoot decreased with increasing sulphate addition rate due to the dilution of the ${ }^{35} \mathrm{SO}_{4}$ tracer by added $\mathrm{SO}_{4}$-S (Fig. 2). When there is oxidation of ES in

(in $\mathrm{mg} \mathrm{kg}^{-1}$ ). The $\%$ SdfES for the ES fertiliser treatments was calculated from $\mathrm{SA}_{\text {plant }}$ according to Eq. (1), using the $\mathrm{SO}_{4}-\mathrm{S}$ only treatment with same $\mathrm{SO}_{4}-\mathrm{S}$ rate as reference

\begin{tabular}{|c|c|c|c|c|c|c|c|c|c|c|}
\hline \multirow[b]{2}{*}{$\begin{array}{l}\text { Treatment } \\
\left(\mathrm{SO}_{4}-\mathrm{S} / \mathrm{ES}\right)\end{array}$} & \multicolumn{5}{|l|}{ First crop } & \multicolumn{5}{|c|}{ Second crop } \\
\hline & $\begin{array}{l}\text { DMY } \\
\left(\text { g pot }^{-1}\right)\end{array}$ & $\begin{array}{l}\mathrm{S}_{\text {shoot }} \\
\left(\mathrm{g} \mathrm{kg}^{-1}\right)\end{array}$ & $\begin{array}{l}\text { S uptake } \\
\left(\mathrm{mg} \mathrm{pot}^{-1}\right)\end{array}$ & $\begin{array}{l}\mathrm{SA}_{\text {plant }} \\
\left(\mathrm{Bq} \mu \mathrm{g}^{-1}\right)\end{array}$ & $\%$ SdfES & $\begin{array}{l}\text { DMY } \\
\left(\mathrm{g} \mathrm{pot}^{-1}\right)\end{array}$ & $\begin{array}{l}\mathrm{S}_{\text {shoot }} \\
\left(\mathrm{g} \mathrm{kg}^{-1}\right)\end{array}$ & $\begin{array}{l}\text { S uptake } \\
\left(\mathrm{mg} \mathrm{pot}^{-1}\right)\end{array}$ & $\begin{array}{l}\mathrm{SA}_{\text {shoot }} \\
\left(\mathrm{Bq} \mu \mathrm{g}^{-1}\right)\end{array}$ & $\%$ SdfES \\
\hline MAP (3.2) & $1.9 \mathrm{bc}$ & $1.1 \mathrm{de}$ & $2.1 \mathrm{e}$ & $134 \mathrm{a}$ & na & $1.5 \mathrm{~cd}$ & $1.0 \mathrm{~b}$ & $1.5 \mathrm{c}$ & $83 \mathrm{a}$ & $n a$ \\
\hline $\operatorname{AS}(6.7)$ & $2.3 \mathrm{ab}$ & $1.4 \mathrm{~d}$ & $3.1 \mathrm{~d}$ & $93 \mathrm{~b}$ & $n a$ & $1.7 \mathrm{bc}$ & $1.0 \mathrm{~b}$ & $1.7 \mathrm{bc}$ & $73 \mathrm{ab}$ & $n a$ \\
\hline AS (10) & $2.6 \mathrm{a}$ & $1.9 \mathrm{c}$ & $4.9 \mathrm{c}$ & $70 \mathrm{c}$ & $n a$ & $1.5 \mathrm{~cd}$ & $1.2 \mathrm{~b}$ & $1.7 \mathrm{bc}$ & $70 \mathrm{~b}$ & $n a$ \\
\hline AS (20) & $2.5 \mathrm{a}$ & $5.5 \mathrm{a}$ & $13.7 \mathrm{a}$ & $36 \mathrm{e}$ & $n a$ & $1.9 \mathrm{ab}$ & $1.3 \mathrm{~b}$ & $2.3 \mathrm{~b}$ & $52 \mathrm{c}$ & na \\
\hline $\mathrm{SB}(3.2 / 16.8)^{\mathrm{a}}$ & $1.6 \mathrm{c}$ & $1.0 \mathrm{e}$ & $1.7 \mathrm{e}$ & $129 \mathrm{a}$ & $4 \mathrm{~b}$ & $1.4 \mathrm{~d}$ & $1.0 \mathrm{~b}$ & $1.4 \mathrm{c}$ & $80 \mathrm{ab}$ & $4 \mathrm{~b}$ \\
\hline SfNP1 $(6.7 / 13.3)^{b}$ & $2.3 \mathrm{ab}$ & $1.9 \mathrm{c}$ & $4.4 \mathrm{c}$ & $71 \mathrm{c}$ & $24 \mathrm{a}$ & $2.0 \mathrm{a}$ & $1.7 \mathrm{a}$ & $3.5 \mathrm{a}$ & $41 \mathrm{~d}$ & $43 \mathrm{a}$ \\
\hline SfNP2 $(10 / 10)^{c}$ & $2.5 \mathrm{a}$ & $2.3 \mathrm{~b}$ & $5.7 \mathrm{~b}$ & $58 \mathrm{~d}$ & $17 \mathrm{ab}$ & $2.0 \mathrm{a}$ & $1.8 \mathrm{a}$ & $3.5 \mathrm{a}$ & $40 \mathrm{~d}$ & $43 \mathrm{a}$ \\
\hline
\end{tabular}

Means within a column not followed by the same letter are significantly different $(P \leq 0.05$, Duncan's multiple range test)

na not applicable

${ }^{\text {a }}$ Sulphur-bentonite pastilles, containing $90 \%$ ES

${ }^{\mathrm{b}} \mathrm{S}$-fortified ammonium phosphate fertiliser with $4 \% \mathrm{SO}_{4}-\mathrm{S}$ and $8 \% \mathrm{ES}$ (Granulock S)

${ }^{\mathrm{c}} \mathrm{S}$-fortified ammonium phosphate fertiliser with $5 \% \mathrm{SO}_{4}-\mathrm{S}$ and $5 \% \mathrm{ES}$ (MicroEssentials SZ) 


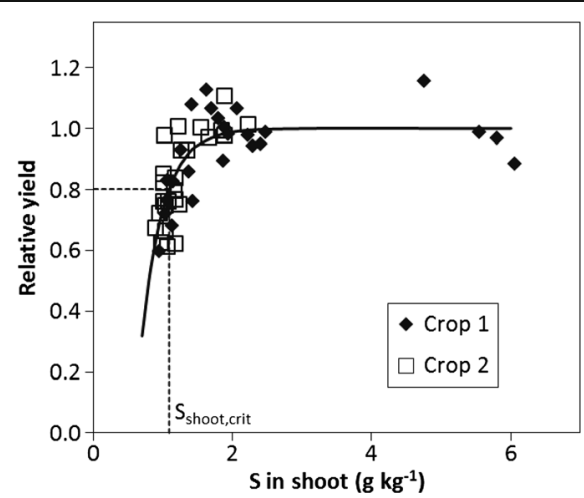

Fig. 1 The relative yield (yield relative to that in non-S limited treatments) for all treatment replicates in the first crop (filled diamonds) and second crop (open squares) as a function of the shoot $\mathrm{S}$ concentration. The exponential curve (Eq. 10) was fitted to the data by least-square regression. The dashed lines indicate the critical shoot $\mathrm{S}$ concentration at which $80 \%$ of the maximal yield is reached

the treatments with ES-containing fertiliser, the additional $\mathrm{SO}_{4}-\mathrm{S}$ results in a further decrease in SA compared to the corresponding $\mathrm{SO}_{4}$-S only treatment. Thus, the SA in the plant could be used to quantify the contribution of ES in the fertiliser to the $\mathrm{S}$ uptake (Eq. 1). The SA in the plant was similar for the SB treatment and the control treatment. The \%SdfES for the SB treatment was not significantly different from 0 in either crop. For the S-fortified NP fertilisers, $\mathrm{SA}_{\text {plant }}$ was significantly lower than in the corresponding reference treatments (Fig. 2 and Table 3). The calculated \%SdfES in the plants was around $20 \%$ in the first crop and around $40 \%$ in the second crop.

The negligible contribution of ES to S uptake in the SB treatment suggests that there was little oxidation of the ES-bentonite pastilles. Visual inspection of the soil after the second crop revealed seemingly intact pastilles, confirming the lack of oxidation even after 2 crops.

Modelling and estimation of the elemental S oxidation rate

Table 4 lists the input parameters and initial conditions used in the model (derivation explained below) and Fig. 3 shows the predicted and observed values for the concentration of $\mathrm{Ca}\left(\mathrm{H}_{2} \mathrm{PO}_{4}\right)_{2}$-extractable $\mathrm{S}$ (as measure of soil sulphate), the shoot yield, the shoot $\mathrm{S}$ concentration and the specific activity in the shoot.

The maximum growth rate was selected to describe the final yield for the non-S limited treatments. Predicted total yield was compared to measured shoot yield assuming that the root consisted $50 \%$ of the total plant mass and of the total plant $\mathrm{S}$. This assumption was based on the fact that the decrease in $\mathrm{SO}_{4}-\mathrm{S}$ concentration in the soil was about twice as high as

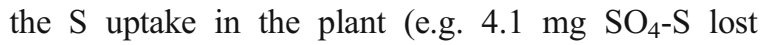
compared to $2.1 \mathrm{mg} \mathrm{S}$ taken up and translocated into shoots for the control treatment). It should be noted that part of this unaccounted-for loss of $\mathrm{SO}_{4}-\mathrm{S}$ may have been due to immobilization in microorganisms or soil organic matter. The value for relative shoot weight (RSW) is thus a fitting parameter to account for $\mathrm{SO}_{4^{-}}$ $\mathrm{S}$ removal from the soil other than by uptake in the shoot. A value of $1.09 \mathrm{~g} \mathrm{~kg}^{-1}$ was selected for the critical shoot $\mathrm{S}$ concentration (corresponding to $80 \%$ RY according to Eq. 10). The uptake coefficient was selected to obtain the best fit of observed shoot $\mathrm{S}$ concentrations. Using the same uptake coefficient for all treatments, a good agreement between observed and predicted shoot $\mathrm{S}$ was obtained, except for the $\mathrm{AS}(20)$ treatment for which the shoot $\mathrm{S}$ was underestimated. Most likely this is related to immobilization of sulphate (which as explained above is accounted for by RSW) being relatively less important at this higher $\mathrm{S}$ rate.

The weight and $\mathrm{S}$ content of four seeds was used as the initial plant weight and initial amount of $S$ in the plant. The initial $\mathrm{SO}_{4}-\mathrm{S}$ concentration in the soil at the start of the first crop was taken as the sum of the $\mathrm{SO}_{4}$ $\mathrm{S}$ concentration $\left(3.1 \mathrm{mg} \mathrm{kg}^{-1}\right)$ in the soil and the $\mathrm{SO}_{4^{-}}$ $\mathrm{S}$ rate added with the fertiliser (Table 2). The initial ${ }^{35} \mathrm{SO}_{4}$-S activity was assumed to be $883 \mathrm{kBq}(\mathrm{kg}$ soil $)^{-1}$. This corresponds to the $\mathrm{Ca}\left(\mathrm{H}_{2} \mathrm{PO}_{4}\right)_{2}$-extractable ${ }^{35} \mathrm{~S}$ at the start of the pot trial (50 days after addition of ${ }^{35} \mathrm{SO}_{4}-\mathrm{S}$ ). This value is about 3 times less than the added ${ }^{35} \mathrm{SO}_{4}-\mathrm{S}$ rate $\left(2.4 \mathrm{MBq} \mathrm{kg}^{-1}\right)$, which can be explained by dilution of ${ }^{35} \mathrm{SO}_{4}$ into the labile organic $\mathrm{S}$ pool. There was little change in the $\mathrm{Ca}\left(\mathrm{H}_{2} \mathrm{PO}_{4}\right)_{2}$-extractable ${ }^{35} \mathrm{~S}$ from 5 weeks after spiking onwards, indicating that the system had reached equilibrium by the start of the pot experiment. Given this initial ${ }^{35} \mathrm{SO}_{4}-\mathrm{S}$ activity of $883 \mathrm{kBq} \mathrm{kg}^{-1}$, the specific activity of soil sulphate at the start of the experiment was $140 \mathrm{~Bq}_{\mathrm{gg}}^{-1}$ for the control treatment (with initially $6.3 \mathrm{mg} \mathrm{SO}_{4}-\mathrm{S} \mathrm{kg}^{-1}$ ), but only $38 \mathrm{~Bq} \mathrm{~g}^{-1}$ for the $\mathrm{AS}(20)$ treatment (with initially $23.1 \mathrm{mg} \mathrm{SO}_{4}-\mathrm{S} \mathrm{kg}^{-1}$ ).

For the initial $\mathrm{SO}_{4}-\mathrm{S}$ concentration at the start of the second crop, $3 \mathrm{mg} \mathrm{kg}^{-1}$ was added to the $\mathrm{SO}_{4}-\mathrm{S}$ concentration predicted at the end of the first crop. This 


\section{Crop 1}
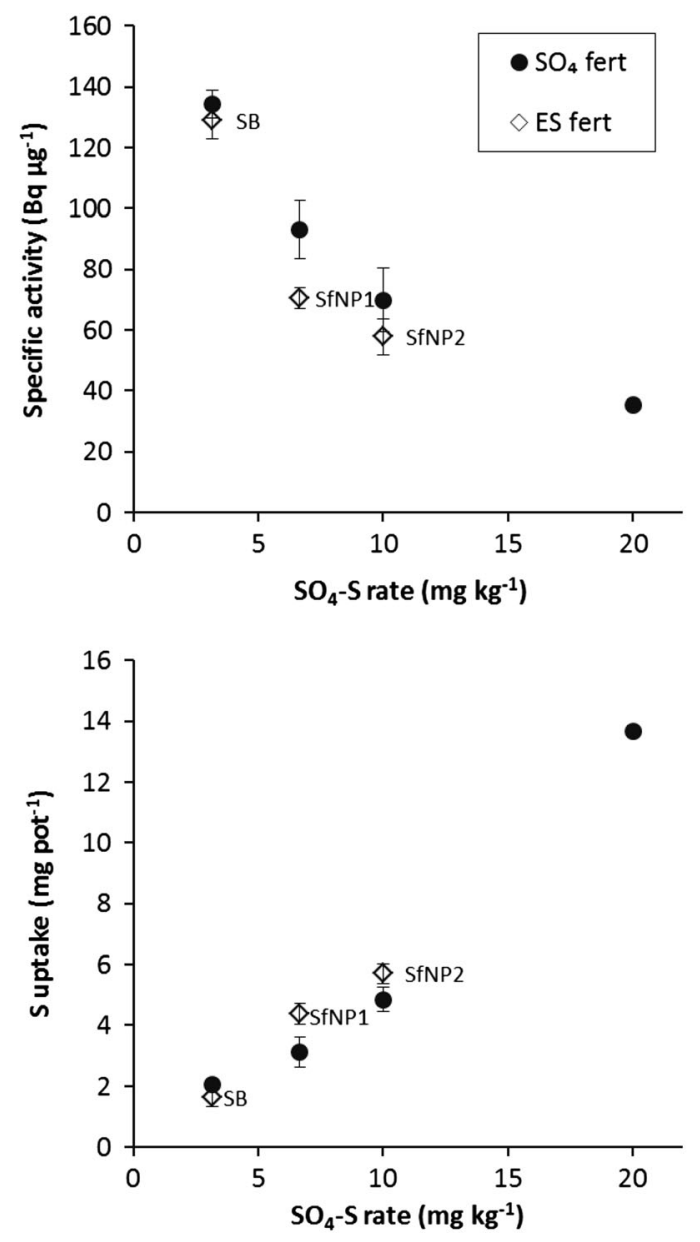

Fig. 2 The specific activity in the shoot or the $\mathrm{S}$ uptake as a function of the added $\mathrm{SO}_{4}-\mathrm{S}$ rate for the first and second crop. The closed circles show treatments with $\mathrm{SO}_{4}-\mathrm{S}$ only and the open diamonds treatments with ES-containing fertilisers (SB: ES-

additional $\mathrm{SO}_{4}$-S supply had to be assumed to explain the growth and uptake in the second crop for the control and SB treatments. Without any input of additional sulphate, the growth and uptake in the second crop was substantially underestimated. We hypothesize that this additional $\mathrm{SO}_{4}$-S supply is due to net mineralization of organic $\mathrm{S}$. This input of additional $\mathrm{SO}_{4}-\mathrm{S}$ is also indicated by the difference in $\mathrm{SA}_{\text {plant }}$ between the first and second crop (Table 3). The SA was higher in the first than in the second crop for the MAP and AS(6.7) treatment, lower for the $\mathrm{AS}(20)$ treatment and similar for the AS(10) treatment (Table 3). To describe this, it was assumed that the soil $\mathrm{S}$ mineralized had the same specific activity as $\mathrm{SO}_{4}-\mathrm{S}$ at the start of the experiment

\section{Crop 2}
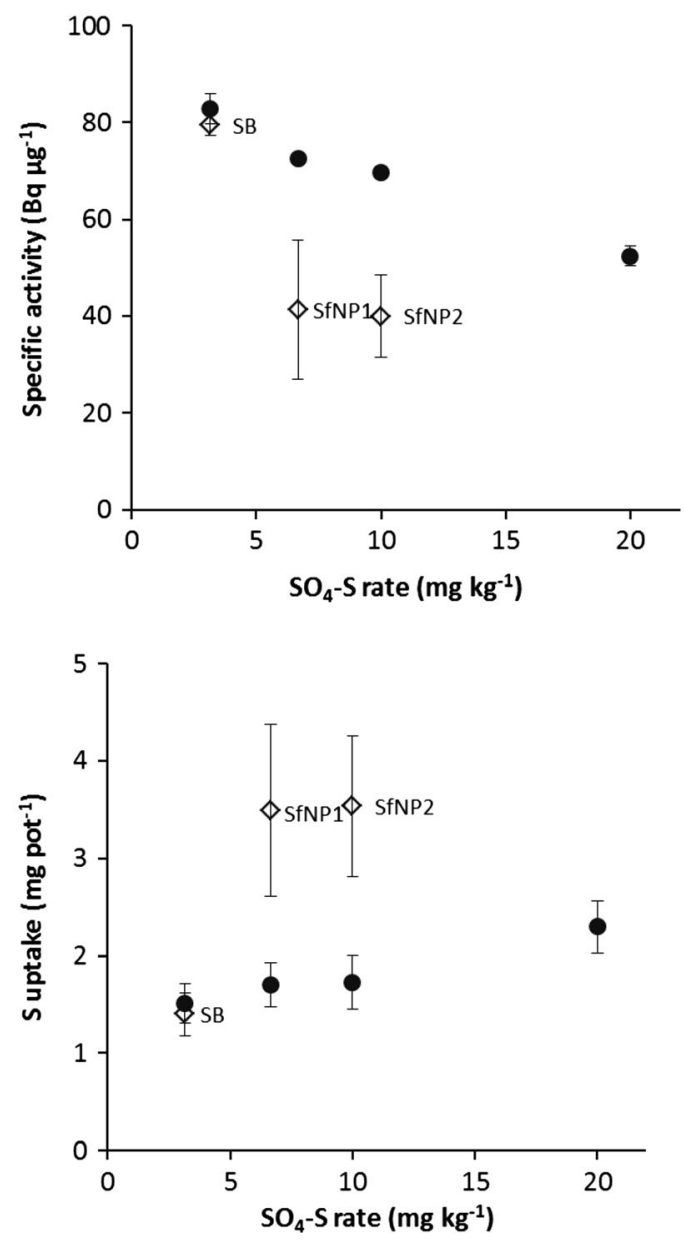

bentonite pastilles; SfNP1 and SfNP2: S-fortified ammonium phosphate fertilisers; see Table 2). Error bars give standard deviations of four replicates

for the $\mathrm{AS}(10)$ treatment, i.e. $67.4{\mathrm{~Bq} \mu \mathrm{g}^{-1}}^{-1}$ $\left(883 \mathrm{kBq} \mathrm{kg}^{-1}\right.$ divided by $13.1 \mathrm{mg} \mathrm{kg}^{-1}$ ). Our model assumes that this mineralization of organic $\mathrm{S}$ occurred between the first and second crop. The mixing of the soil and partial drying and rewetting before the second crop may indeed have promoted mineralization. However, mineralization may also have occurred partly during the second crop. The dynamics of S mineralization/ immobilization are outside the scope of this study, and it was found that other assumptions about when net mineralization occurred had negligible effect on the overall prediction and the estimated oxidation rates.

The oxidation of ES results in greater $\mathrm{SO}_{4}-\mathrm{S}$ supply and hence in higher $\mathrm{S}$ uptake and lower specific activity 
Table 4 Parameter values and initial conditions used for the modelling (Fig. 3)

\begin{tabular}{|c|c|}
\hline Parameter & Value \\
\hline Max relative growth rate, $\mu_{\max }\left(\mathrm{d}^{-1}\right)$ & 0.15 \\
\hline Uptake coefficient, $\alpha\left(\mathrm{kg}(\mathrm{g} \mathrm{DW})^{-1} \mathrm{~d}^{-1}\right)$ & 0.04 \\
\hline Relative shoot weight, RSW (-) & 0.50 \\
\hline $\begin{array}{l}\text { Critical S concentration, }\left[\mathrm{S}_{\text {plant }}\right]_{\text {crit }} \\
\left(\mathrm{mg}(\mathrm{g} \mathrm{DW})^{-1}\right)\end{array}$ & 1.09 \\
\hline \multicolumn{2}{|l|}{ Oxidation rate constant, $k_{\text {oxid }}\left(\mathrm{d}^{-1}\right)$} \\
\hline $\mathrm{SB}^{\mathrm{a}}$ & 0.0003 \\
\hline SfNP1 ${ }^{b}$ & 0.006 \\
\hline $\mathrm{SfNP} 2^{\mathrm{c}}$ & 0.007 \\
\hline \multicolumn{2}{|l|}{ Initial conditions } \\
\hline $\mathrm{W}_{\text {plant,ini }}(\mathrm{g})$ & 0.009 \\
\hline$\left[\mathrm{S}_{\text {plant }}\right]_{\text {ini }}\left(\mathrm{mg}(\mathrm{g} \mathrm{DW})^{-1}\right)$ & 3 \\
\hline$\left[\mathrm{SO}_{4}\right]_{\text {ini }}\left(\mathrm{mg} \mathrm{S} \mathrm{kg}^{-1}\right)^{\mathrm{d}}$ & $3.1+\left[\mathrm{SO}_{4}\right]_{\text {fert }}$ \\
\hline $\mathrm{SA}_{\mathrm{SO} 4, \text { ini }}\left(\mathrm{Bq} \mu \mathrm{g}^{-1}\right)$ & $883 /\left[\mathrm{SO}_{4}\right]_{\mathrm{ini}}$ \\
\hline$\left[\mathrm{SO}_{4}\right]_{\text {mineralized }}\left(\mathrm{mg} \mathrm{S} \mathrm{kg}^{-1}\right)^{\mathrm{e}}$ & 3.0 \\
\hline $\mathrm{SA}_{\mathrm{SO} 4, \text { mineralized }}\left(\mathrm{Bq} \mu \mathrm{g}^{-1}\right)^{\mathrm{e}}$ & 67.4 \\
\hline
\end{tabular}

${ }^{a}$ Sulphur-bentonite pastilles, containing $90 \%$ ES

${ }^{\mathrm{b}} \mathrm{S}$-fortified ammonium phosphate fertiliser with $4 \% \mathrm{SO}_{4}-\mathrm{S}$ and $8 \%$ ES (Granulock S)

${ }^{\mathrm{c}} \mathrm{S}$-fortified ammonium phosphate fertiliser with $5 \% \mathrm{SO}_{4}$-S and $5 \%$ ES (MicroEssentials SZ)

${ }^{\mathrm{d}}$ The initial sulphate $\mathrm{S}$ concentration was taken as the sum of soil sulphate $\left(3.1 \mathrm{mg} \mathrm{S} \mathrm{kg}^{-1}\right)$ and the sulphate rate added with the fertiliser (Table 2)

e $3 \mathrm{mg} \mathrm{S} \mathrm{kg}^{-1}$ with specific activity of $67.4 \mathrm{~Bq} \mathrm{\mu g}^{-1}$ was assumed to be mineralized between the first and the second crop (see text)

in the plant compared to the corresponding $\mathrm{SO}_{4}-\mathrm{S}$ only treatments. The oxidation rate could hence be estimated by adjusting the oxidation rate constant to obtain the best agreement between observed and predicted $\mathrm{SA}_{\text {plant }}$. This resulted in an estimate of $0.6 \%$ per day for SfNP1, $0.7 \%$ per day for SfNP2, and $0.03 \%$ per day oxidation for SB (ES pastilles). There was considerable variation in $\mathrm{SA}_{\text {plant }}$ between replicates for the S-fortified NP fertilisers and $\mathrm{SA}_{\text {plant }}$ was strongly negatively correlated with shoot $\mathrm{S}$ and $\mathrm{S}$ uptake. If the oxidation rate was fitted on the individual replicates, estimates varied about 3 -fold between replicates $(0.25-0.9 \%$ per day for SfNP1 and $0.35-1.2 \%$ per day for SfNP2).

It should be noted that specific activities were also determined for the $\mathrm{Ca}\left(\mathrm{H}_{2} \mathrm{PO}_{4}\right)_{2}$-extractable $\mathrm{S}$, but these data were not used in the model parameterization. The $\mathrm{SA}$ of $\mathrm{Ca}\left(\mathrm{H}_{2} \mathrm{PO}_{4}\right)_{2}$-extractable $\mathrm{S}$ ranged between 36 and $58 \mathrm{~Bq} \mathrm{\mu g}^{-1}$ at the end of first crop and between 30 and

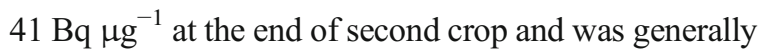
lower than the SA in the plant, particularly for the treatments with low added $\mathrm{SO}_{4}-\mathrm{S}$. This is likely due to the presence of dissolved organic $\mathrm{S}$ in the extract with lower SA than soil $\mathrm{SO}_{4}-\mathrm{S}$. The $\mathrm{Ca}\left(\mathrm{H}_{2} \mathrm{PO}_{4}\right)_{2}$-extractable $\mathrm{S}$ concentrations at the end of the incubation were low, so even small concentrations of dissolved organic $\mathrm{S}$ would have had a large effect on the SA of extracted S.

Overall, this simple model gave a good prediction of soil $\mathrm{SO}_{4}$-S depletion, plant growth, $\mathrm{S}$ uptake and $\mathrm{SA}$ in the plant using the same parameter values for all treatments except for the oxidation rate constant of ES in the ES-containing fertilisers (Fig. 3). We did not make measurements during plant growth, and therefore cannot evaluate the predicted trends during the plant growth period. However, the aim of the model was not to give a detailed description of the dynamics of the system, but to derive an estimate of the rate of ES oxidation (i.e. supply of available $\mathrm{S}$ ) in commercial ES-containing fertilisers. It was found that changing the assumptions of our modelling (e.g. regarding the shape of the plant growth curve or the timing of mineralization) had almost no effect on the estimated oxidation rate, indicating the robustness of this estimate.

\section{Discussion}

\section{Oxidation rate of ES}

The estimated oxidation rate of ES was around 0.6$0.7 \%$ per day for the S-fortified NP fertilisers and around $0.03 \%$ per day for the ES pastilles. These values are similar to the ones determined in a column incubation experiment with three soils from US, Canada and Brazil (Degryse et al. 2015), in which oxidation rates were around $0.5 \%$ per day for Sfortified NP fertilisers with 5-7.5\% ES and around $0.06 \%$ per day for ES pastilles.

The oxidation of ES in the S-fortified NP fertilisers was much faster than for the ES pastilles, but has been shown to be slower than for ES particles of same size (as the particles in the fortified fertiliser) mixed through soil (Degryse et al. 2015). This is most likely due to the reduction in the effective ES surface area when ES is cogranulated (Friesen 1996).

To our knowledge, there are no other studies that have determined the oxidation rate of ES in cogranulated $\mathrm{P}$ fertilisers, but other studies have also 
$\operatorname{MAP}(3.2)$
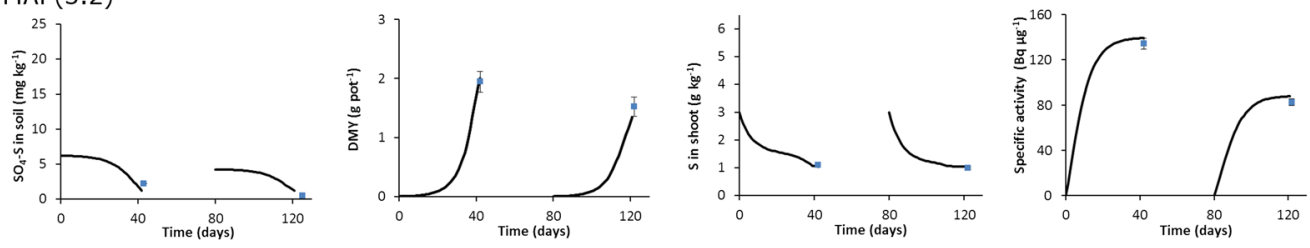

AS(6.7)
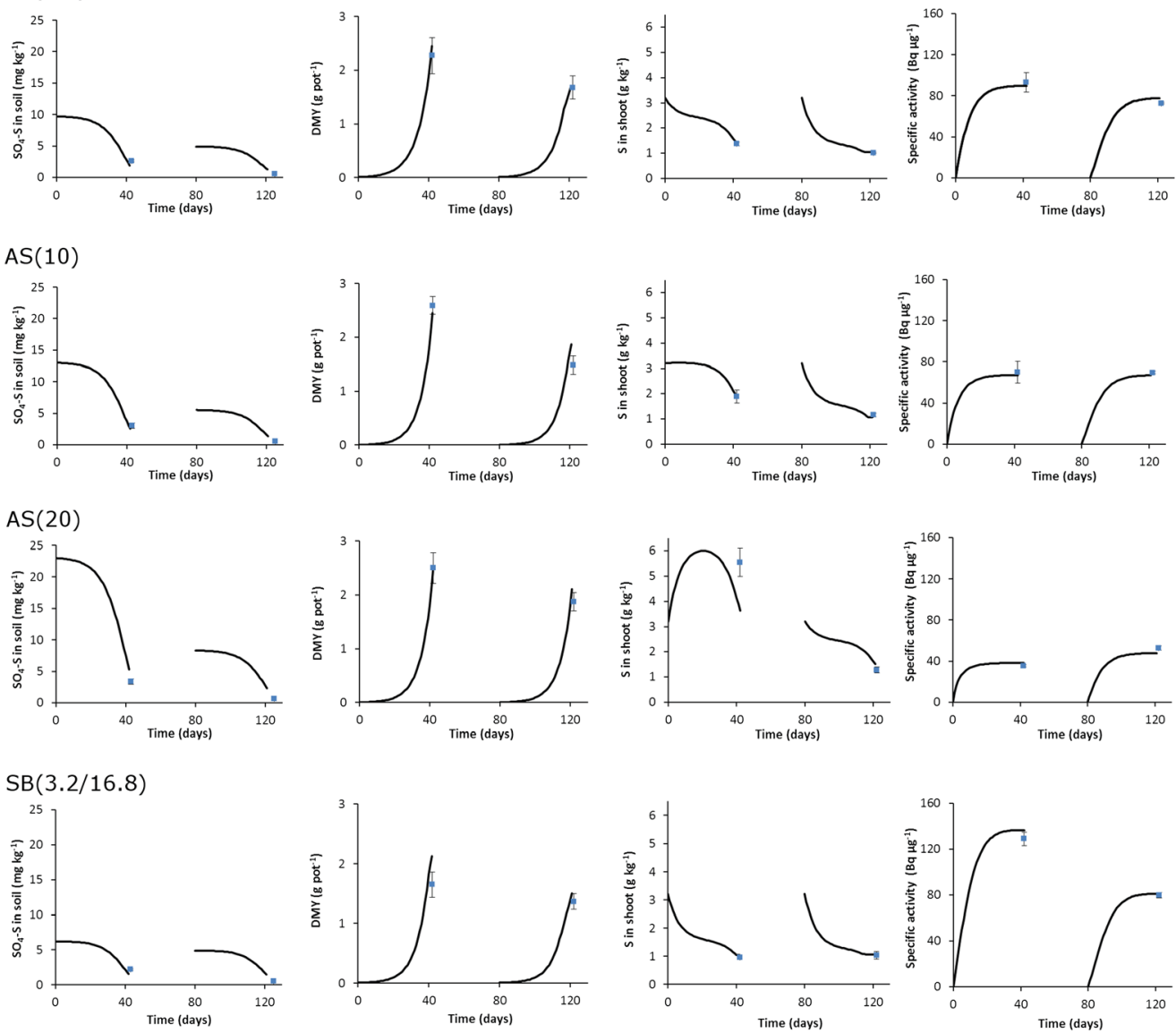

SfNP1(6.7/13.3)
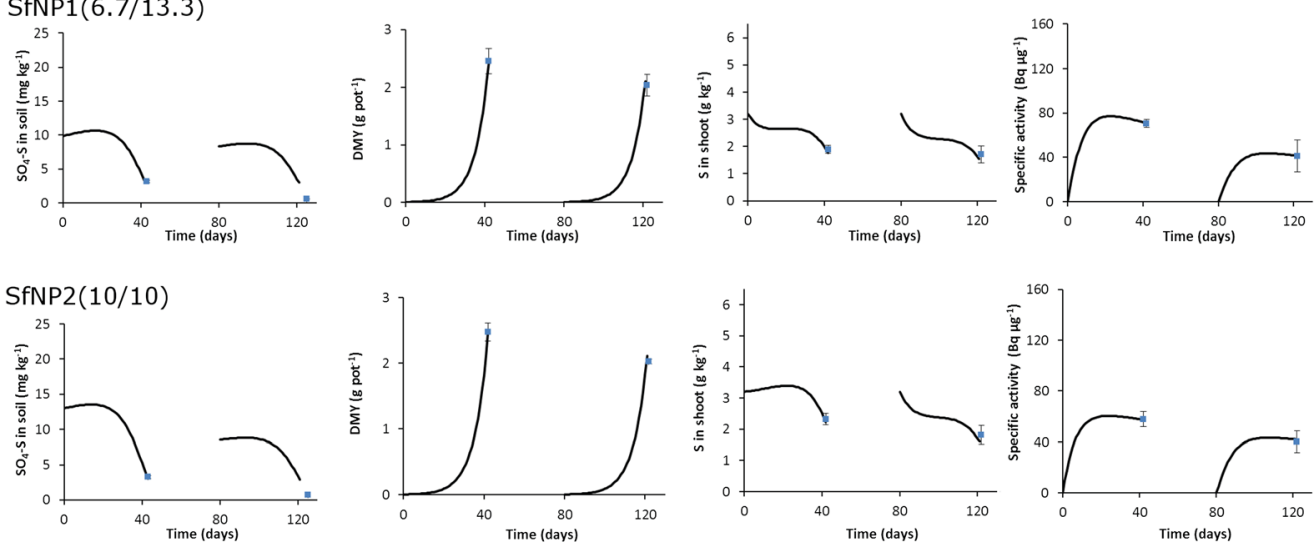
Fig. 3 Observed (symbols) and predicted (lines) sulphate concentration in the soil, shoot dry matter yield (DMY), S concentration in the shoot and specific activity of shoot $\mathrm{S}$, as a function of time (day $0=$ start of first crop; day $80=$ start of second crop). The fertiliser treatments (indicated by the label at the top left for each row of graphs) are listed in Table 2; the values in brackets following the treatment name indicate the added $\mathrm{SO}_{4}-\mathrm{S}$ and ES rate (in $\mathrm{mg} \mathrm{kg}^{-1}$ ). The parameter and initial values used for the modelling are listed in Table 4. Error bars give standard deviations of four replicates

indicated very slow oxidation of ES in ES-bentonite pastilles. For instance, Slaton et al. (2001) estimated oxidation rates of $0.02-0.06 \%$ per day for three types of ES pastilles (with the lower value for the bigger pastilles and the higher value for smaller pastilles). Solberg et al. (2005) measured $\mathrm{SO}_{4}-\mathrm{S}$ in soils incubated with different ES fertilisers and found very low $\mathrm{SO}_{4}-\mathrm{S}$ recoveries for various ES-bentonite products $(<3 \%$ of applied ES after 12 weeks), while fine ES powder mixed through soil showed $\mathrm{SO}_{4}$-S recovery around 50-60\% after only 6 weeks. The slow oxidation of ES-bentonite pastilles can be explained by these pastilles behaving as a single large ES particle, resulting in very slow oxidation (Degryse et al. 2015).

\section{Contribution of ES-derived sulphur to plant uptake}

In the first crop, $\mathrm{S}$ uptake was mostly related to the application rate of $\mathrm{SO}_{4}-\mathrm{S}$ (Fig. 2), but the shoot $\mathrm{S}$ concentrations and $\mathrm{S}$ uptake were greater for the $\mathrm{S}$ fortified NP fertilisers than for the corresponding $\mathrm{SO}_{4}$ $\mathrm{S}$ only treatment with the same added $\mathrm{SO}_{4}-\mathrm{S}$ rate. It was estimated based on the SA of shoot $\mathrm{S}$ that on average $24 \%$ (SfNP1) or $17 \%$ (SfNP2) of S in the plants was derived from the ES in these fertilisers. This agrees with the estimated oxidation rates. The oxidation rate of $0.6 \%$ per day for SfNP1 would have resulted in $22 \%$ ES being oxidized by the end of the first crop (cf. Eq.4; $\left.1-\exp \left(-0.006 \mathrm{~d}^{-1} \times 42 \mathrm{~d}\right)=0.22\right)$, corresponding to $2.9 \mathrm{mg}$ of the $13.3 \mathrm{mg}$ ES oxidized. Given that there was initially $9.8 \mathrm{mg} \mathrm{SO}_{4}$-S per pot for the SfNP1 treatment $(6.7 \mathrm{mg}$ added with SfNP1 and $3.1 \mathrm{mg}$ present in the soil), the oxidized ES would have accounted for $23 \%(=2.9 /(9.8+2.9))$ of the $\mathrm{SO}_{4}-\mathrm{S}$ (=plant-available) pool. Similarly, the oxidation rate of $0.7 \%$ per day for SfNP2 would have resulted in $25 \%$ ES being oxidized by the end of the first crop $(1-\exp (-0.007 \times 42)=0.25)$, corresponding to $2.5 \mathrm{mg}$ of the $10 \mathrm{mg}$ oxidized, which would have accounted for $16 \%$ of the total $\mathrm{SO}_{4}-\mathrm{S}$ pool, as there was initially $13.1 \mathrm{mg} \mathrm{SO}_{4}$-S in soil and fertiliser. There were no differences in $\mathrm{S}$ uptake or $\mathrm{SA}_{\text {plant }}$ between the SB (ES pastille) and the control (MAP) treatment, indicating negligible contribution from the ES in the pastilles due to slow oxidation.

In the second crop, the response to added $\mathrm{SO}_{4}$-S was much less obvious (Fig. 2). The uptake of $\mathrm{S}$ for the Sfortified NP fertilisers in the second crop was about 2fold higher than for the corresponding AS treatments, pointing to a large contribution of ES in these fertilisers to the uptake. This was also evident from the much lower SA in the plant shoots for these treatments than for the corresponding AS treatments. It was estimated that on average, $43 \%$ of the $\mathrm{S}$ in the plant was derived from fertiliser ES. The lack of response to $\mathrm{SO}_{4}-\mathrm{S}$ and the large contribution of ES to the $\mathrm{S}$ uptake in the second crop can be explained by luxury uptake of $\mathrm{SO}_{4}-\mathrm{S}$ in the first crop (as there was no leaching loss of $\mathrm{SO}_{4}-\mathrm{S}$ from the closed pots). The $\mathrm{S}$ uptake in the AS treatments increased proportionally to the $\mathrm{SO}_{4}-\mathrm{S}$ rate, indicating that there was no saturation in the uptake. This resulted in depletion of $\mathrm{SO}_{4}$-S even at the highest $\mathrm{AS}$ rate, resulting in low $\mathrm{S}$ availability in the second crop. The ES in the ES-fortified fertilisers, on the other hand, further oxidized during the second crop, resulting in a continuing supply of $\mathrm{SO}_{4}-\mathrm{S}$. Based on the estimated oxidation rates, it is estimated that about $30 \%$ of the ES in these fertilisers oxidized between the end of the first and the end of the second crop, which would have delivered about $3.9 \mathrm{mg}$ (SfNP1) or $3.2 \mathrm{mg}$ (SfNP2) $\mathrm{SO}_{4^{-}}$ $\mathrm{S}$ per pot. As in the first crop, the ES pastilles made a negligible contribution to the $\mathrm{S}$ uptake in the second crop.

An ES-bentonite pastille is made up of small ES particles. The pastilles are supposed to disintegrate under field conditions, aided by rainfall and freeze/thaw cycles. Disintegration of the pastilles appears to be essential, otherwise each pastille acts as a single large ES particle, resulting in very slow oxidation (Degryse et al. 2015). Boswell et al. (1988b) found that easily dispersible surface-applied ES prills disintegrated quickly and already had a large contribution to $\mathrm{S}$ uptake in the first year of application. However, because of physical constraints, disintegration of the pastilles is unlikely to occur when the pastilles are incorporated in the soil. In this experiment, intact pastilles were still sighted in the soil after the second crop, despite thorough mixing of the soil at the end of the first crop. Similarly, we recovered intact granules from soil 
columns at the end of an extended (up to 56 weeks) column leaching experiment (Degryse et al. 2015). Riley et al. (2000) carried out a 2-year pot trial in which the $\mathrm{S}$ fertilisers were initially surface-applied and soils mixed thoroughly after the first crop. They also found low performance of ES-bentonite prills even though the prills were initially surface-applied, and found that exposing the prills to freeze-thaw episodes did not increase their effectiveness. Most field trials have also indicated little contribution to crop S uptake of ES pastilles or prills in the first year after application (Grant et al. 2012; Janzen and Karamanos 1991; Malhi et al. 2008; Solberg et al. 2007). Some studies have reported that the residual effect of ES pastilles in a second or third year is similar to that of $\mathrm{SO}_{4}$-S fertiliser (Janzen and Karamanos 1991; Solberg et al. 2007), but this was without re-application of $\mathrm{SO}_{4}-\mathrm{S}$ fertiliser. Recovery of $\mathrm{SO}_{4}$-S fertiliser usually sharply declines after the first year (Janzen and Karamanos 1991), which can be explained by high uptake of $\mathrm{SO}_{4}$-S in the first year and possibly immobilization and leaching of $\mathrm{SO}_{4}-\mathrm{S}$ below the root zone prior to plant uptake in subsequent crops. Hence, the fact that several studies found similar effects of ES pastilles/prills and $\mathrm{SO}_{4}$-S fertilisers in a second or third year does not necessarily point to a high residual effect of the pastilles, but rather to a low residual effect of the $\mathrm{SO}_{4}-\mathrm{S}$ fertiliser.

In contrast to the ES pastilles, there was a large contribution of ES to the S uptake for the S-fortified NP fertilisers in the second crop. Few literature studies have assessed the contribution of ES to $\mathrm{S}$ uptake by plants for S-fortified granular fertilisers. Friesen (1996) assessed S uptake from gypsum and various ES-fortified fertilisers (around $16 \%$ ES, ES diameter $<0.15 \mathrm{~mm}$, granule diameter $1.7-3.4 \mathrm{~mm}$ ) in a 6 week pot experiment with maize. He found that maximum growth was obtained with gypsum at $15 \mathrm{mg} \mathrm{S} \mathrm{kg}{ }^{-1}$ or with the ES-fortified TSP and DAP fertilisers at $135 \mathrm{mg} \mathrm{S} \mathrm{kg}{ }^{-1}$, suggesting that about $10 \%$ of the ES was oxidized over the experimental period. In a longer-term pot trial with rice (grown to maturity; duration not specified), S uptake from single superphosphate applied at $20 \mathrm{mg} \mathrm{S} \mathrm{kg}^{-1}$ was similar to the uptake from the ES-fortified TSP applied at $80 \mathrm{mg} \mathrm{S} \mathrm{kg}^{-1}$, suggesting $25 \%$ oxidation of ES over the experimental period (likely around 100 days) (Friesen 1996). This is a circa 2-fold slower oxidation rate than we estimated in the current study for the S-fortified NP fertilisers, which might be related to the higher ES content of the fertiliser (resulting in a lower effective surface area) or to other differences in the experimental conditions (soil, temperature, etc.).

In conclusion, this study assessed the oxidation rate and contribution of ES to plant uptake for commercial ES-containing fertilisers. The results of this study indicated that about $50-60 \%$ of ES in S-fortified NP fertilisers (with 8 or $5 \%$ ES) was oxidized over a 120 day period. In contrast, there was very little oxidation of the ES pastilles, resulting in negligible contribution to the plant uptake over the experimental period. While fertiliser $\mathrm{SO}_{4}-\mathrm{S}$ contributed most to the uptake in the first crop, ES in the S-fortified fertilisers had a large contribution to the $\mathrm{S}$ uptake in the second crop, due to depletion of $\mathrm{SO}_{4}-\mathrm{S}$ by the first crop. Thus, incorporation of both $\mathrm{ES}$ and $\mathrm{SO}_{4}-\mathrm{S}$ in the $\mathrm{S}$-fortified fertilisers sustained the plant $\mathrm{S}$ demand over a longer period than $\mathrm{SO}_{4}-\mathrm{S}$ alone.

Acknowledgments This work was supported by the Mosaic Company. We also thank Bogumila Tomczak, Colin Rivers, Ashleigh Broadbent and Deepika Setia for technical assistance.

Open Access This article is distributed under the terms of the Creative Commons Attribution 4.0 International License (http:// creativecommons.org/licenses/by/4.9/), which permits use, duplication, adaptation, distribution and reproduction in any medium or format, as long as you give appropriate credit to the original author(s) and the source, provide a link to the Creative Commons license and indicate if changes were made.

\section{References}

Barber SA (1995) Soil nutrient bioavailability: a mechanistic approach. John Wiley \& Sons, Inc, New York

Barrow NJ (1967) Studies on extraction and on availability to plants of adsorbed plus soluble sulfate. Soil Sci 104:242-249

Bender RR, Haegele JW, Ruffo ML, Below FE (2013) Nutrient uptake, partitioning, and remobilization in modern, transgenic insect-protected maize hybrids. Agron J 105:161-170

Boswell CC, Friesen DK (1993) Elemental sulfur fertilizers and their use on crops and pastures. Fert Res 35:127-149

Boswell CC, Owers WR, Swanney B, Rothbaum HP (1988a) Sulfur/sodium bentonite mixtures as sulfur fertilizers. 1 . The effects of S/Na-bentonite ratios on the rate of dispersion and particle size distribution of elemental sulfur dispersed from laboratory-produced prills. Fert Res 15:13-31

Boswell CC, Swanney B, Owers WR (1988b) Sulfur/sodium bentonite prills as sulfur fertilizers. 2. Effect of sulfursodium bentonite ratios on the availability of sulfur to pasture plants in the field. Fert Res 15:33-45

Ceccotti SP (1996) Plant nutrient sulphur-a review of nutrient balance, environmental impact and fertilizers. Fert Res 43: $117-125$ 
Chien SH, Gearhart MM, Villagarcía S (2011) Comparison of ammonium sulfate with other nitrogen and sulfur fertilizers in increasing crop production and minimizing environmental impact: a review. Soil Sci 176:327-335

Degryse F, Ajiboye B, Baird R, da Silva RC, McLaughlin MJ (2015) Oxidation of elemental sulfur in granular fertilizers. Submitted to Soil Sci Soc Am J

Friesen DK (1996) Influence of co-granulated nutrients and granule size on plant responses to elemental sulfur in compound fertilizers. Nutr Cycl Agroecosyst 46:81-90

Germida JJ, Janzen HH (1993) Factors affecting the oxidation of elemental sulfur in soils. Fert Res 35:101-114

Grant CA, Mahli SS, Karamanos RE (2012) Sulfur management for rapeseed. Field Crops Res 128:119-128

Haneklaus S, Bloem E, Schnug E (2008) History of sulfur deficiency in crops. In: Jez J (ed) Sulfur: a missing link between soils, crops, and nutrition. ASA-CSSA-SSSA, Masidon, pp 45-58

Janzen HH, Bettany JR (1987) The effect of temperature and water potential on sulfur oxidation in soils. Soil Sci 144:81-89

Janzen HH, Karamanos RE (1991) Short-term and residual contribution of selected elemental S fertilizers to the $\mathrm{S}$ fertility of two Luvisolic soils. Can J Soil Sci 71:203-211

Karamanos RE, Janzen HH (1991) Crop response to elemental sulfur fertilizers in central Alberta. Can J Soil Sci 71:213-225

Malhi SS, Schoenau JJ, Vera CL (2008) Feasibility of elemental S fertilizers for optimum seed yield and quality of canola in the Parkland region of the Canadian Great Plains. In: Khan NA, Singh S, Umar S (eds) Sulfur Assimilation and Abiotic Stress in Plants. Springer-Verlag, Berlin Heidelberg, pp 21-41

Matejovic I (1997) Determination of carbon and nitrogen in samples of various soils by the dry combustion. Commun Soil Sci Plant Anal 28:1499-1511

McKenzie NJ, Coughlan KJ, Cresswell HP (2002) Soil physical measurements and interpretation for land evaluation. CSIRO Publishing, Collingwood
Morel FMM, Hudson RJM, Price NM (1991) Limitation of productivity by trace metals in the sea. Limnol Oceanogr 36:1742-1755

Pinkerton A (1998) Critical sulfur concentrations in oilseed rape (Brassica napus) in relation to nitrogen supply and to plant age. Aust J Exp Agric 38:511-522

Rayment GE, Higginson FR (1992) Australian laboratory handbook of soil and water chemical methods. Inkata Press, Melbourne

Riley NG, Zhao FJ, McGrath SP (2000) Availability of different forms of sulphur fertilisers to wheat and oilseed rape. Plant Soil 222:139-147

Scherer HW (2001) Sulphur in crop production - invited paper. Eur J Agron 14:81-111

Slaton NA, Norman RJ, Gilmour JT (2001) Oxidation rates of commercial elemental sulfur products applied to an alkaline silt loam from Arkansas. Soil Sci Soc Am J 65:239-243

Solberg ED, Malhi SS, Nyborg M, Gill KS (2003) Fertilizer type, tillage, and application time effects on recovery of sulfate-S from elemental sulfur fertilizers in fallow field soils. Commun Soil Sci Plant Anal 34:815-830

Solberg ED, Malhi SS, Nyborg M, Gill KS, Henriquez B (2005) Source, application method, and cultivation effects on recovery of elemental sulfur as sulfate-S in incubated soils. Commun Soil Sci Plant Anal 36:847-862

Solberg ED, Malhi SS, Nyborg M, Henriquez B, Gill KS (2007) Crop response to elemental $\mathrm{S}$ and sulfate-S sources on $\mathrm{S}$ deficient soils in the parkland region of Alberta and Saskatchewan. J Plant Nutr 30:321-333

Watkinson JH (1989) Measurement of the oxidation rate of elemental sulfur in soil. Soil Res 27:365-375

Zhao F, McGrath SP (1994) Extractable sulphate and organic sulphur in soils and their availability to plants. Plant Soil 164:243-250

Zhao FJ, McGrath SP, Blake-Kalff MMA, Link A, Tucker M (2002) Crop responses to sulphur fertilisation in Europe. Proceedings No. 504. International Fertiliser Society, York 